Baris Bahceci, Associate Professor

Izmir University of Economics, Turkey

\title{
QUESTIONING THE PENAL CHARACTER OF DISCIPLINARY SANCTIONS IN THE EUROPEAN COURT OF HUMAN RIGHTS' CASE LAW
}

\begin{abstract}
Summary
Since the European Court of Human Rights (Court) has autonomously redefined the concept of penalty, it has extended its jurisdiction. However, unless they deprive of liberty, disciplinary sanctions are excluded from this autonomous definition. In this respect, this case law study depicts the Court's approach to disciplinary sanctions and particularly focuses on problems arising from the implementation. From a descriptive point of view, exceptional status for disciplinary sanctions depends on two factors: The first factor is the criteria that was developed by the Court to assess whether autonomous penalties contain a structural incompatibility. In order to prove this argument, the practices indicating the discrepancy between the criteria of the "nature of offence" and the "nature of sanction" will be examined. A critical analysis of this situation shows that if these criteria are used in their current form, the problem will persist, and therefore a reinterpretation is needed. The second factor is the definition of disciplinary sanction undertaken by the Court. The phrase "special" in this definition creates uncertainty in terms of scope, and has controversial results. Therefore, these two factors need to be reviewed in order to ensure that the Court's case law on disciplinary sanctions yields more objective and consistent results.
\end{abstract}

Keywords: ECtHR case law, concept of penalty, disciplinary sanction, criminal offence, nature of offence, nature of sanction

\section{Introduction}

Until 1976, the guarantees concerning criminal issues that involve in the European Convention on Human Rights (ECHR/Convention) ${ }^{1}$ applied only to the sanctions that are classified as penalty in the domestic law of Contracting States. In that year, the European Court of Human Rights (ECtHR/Court) initially created an autonomous concept of penalty by specific criteria in the Engel judgment. ${ }^{2}$ According to these criteria, called Engel criteria in the subsequent cases, the concept of penalty was redefined regardless of the subjective classification of the Contracting States. By means of this dynamic interpretation, ${ }^{3}$ the Court gradually has widened its

1 Convention for the Protection of Human Rights and Fundamental Freedoms. Signed in Rome, 4.11.1950.

2 Engel and the others $v$. the Netherlands $\$ 80-85$.

3 Harris D., O'Boyle M., Bates E., Buckley C. Law of the European Convention on Human Rights. New York: Oxford University Press, 2014, p. 7. 
ratione materiae, and consequently expanded the implementation of the ECHR and the guarantees therein. However, as the disciplinary sanctions are largely excluded from this implementation, the persons on whom such sanctions are imposed are confronted with negative effects from this interpretation.

These effects could be summed up under two contexts. The first effect is relatively insignificant, and concerns only the rights of access to a court and hearing involving in the first paragraph of Article $6 \$ 1$ of the Convention. ${ }^{4}$ Since these rights are provided not only in criminal but also in civil disputes under this article, the Court considers them as civil disputes, and implements these rights therein. ${ }^{5}$ The second effect, however, deprives the disciplinary sanctions completely of the guarantees in the Convention. ${ }^{6}$

In this respect, the purpose of this study is to analyse and criticize the conceptual point of the view in jurisprudence under two controversial facts. The first of these is the subjective consequences of the concept of penalty defined according to Engel criteria in terms of disciplinary sanctions. The second is inconsistent and uncertain characteristic of the definition of disciplinary sanctions defined by the Court. Therefore, (1) the questions arising from the application of the Engel criteria and (2) the questions arising from the definition of disciplinary sanctions made by the ECtHR will be examined under the following headings.

\section{Questioning the criteria developed by the court}

The basis of the case law on assessing the concept of penalty is the three Engel criteria, as follows: "(1) the legal classification of the offence under national law, (2) the very nature of the offence and (3) the degree of severity of the penalty that the person concerned risks incurring". The first criterion is rarely used and has no decisive role in terms of the classification of disciplinary sanctions. However, the other two directly and indirectly determine whether disciplinary sanctions are included in the definition of penalty.

In this context, firstly (1) the nature of these offences will be questioned within the framework of the second criterion, which directly removes disciplinary sanctions from the concept of penalty. Then, (2) the impact of the third criterion on this assessment, and the conflicting relationship this causes will be discussed.

4 Article $6 \$ 1$ : "in the determination of his civil rights and obligations or of any criminal charge against him, everyone is entitled to a fair and public hearing within a reasonable time by an independent and impartial tribunal established by law".

5 Albert and Le Comte v Belgium $\$ 30$.

6 In this context, presumption of innocence (Article $6 \$ 2$ ), right to be informed and adequate time for defence, right to legal assistance and attendance and examination of witnesses, right to assistance of an interpreter (Article $6 \$ 3$ ) will not be applied. In the same line, since it is not considered a criminal offence any disciplinary sanctions shall not be considered within the framework of the prohibition to penalization without law and retroactive practice (Article $7 \$ 1$ ), and the right of appeal (Article 2 of Protocol 7) shall not be deemed. Finally, the rule of ne bis in idem (Article 4 of the Protocol 7), that prevents multiple punishments, will not provide protection to the respondents. 


\subsection{What is the nature of a disciplinary offence?}

In the Court's case law, disciplinary sanctions are considered outside the scope of the concept of penalty on the basis of the second criterion. However, this interpretation creates considerable challenges in terms of its literal meaning. First of all, while the nature of sanction belongs to the third criterion, it is tautological to mention the nature of the offence ${ }^{7}$, i.e. the second criterion is far from its literal meaning.

From a chronological point of view, in the Öztürk judgment, the nature of offence was explained by the distinction as to whether the offence could be processed by a limited group, or by everyone. ${ }^{8}$ According to this point of view, not only disciplinary sanctions, but also other offences that can be committed by anyone in the nature of sanctions to be applied to them would be a penalty.

In the Weber judgment, this phrase turned into "potentially affects the whole population". In other words, the focus is not the offence, but the sanction itself as it should be. ${ }^{9}$ This point of view focuses on the perpetrator of the offence sanction, not the addressees. This means that the distinguishing feature implied in this criterion is not the number of addressees, but their quality as members of a particular group, combined with the interests protected by the rule. ${ }^{10}$

\subsection{What is the nature and the severity of a disciplinary sanction?}

The nature and the severity of a disciplinary sanction (third criterion) is inconsistent with the second criterion, and its own elements are contradictory. While the nature of sanction is a qualitative feature, the severity of sanction is based on quantity. Therefore, the interaction between them should be examined separately.

In the case law, "the concept of nature" has developed on two separate models depending on two judgments of the Court. ${ }^{11}$ According to this duality, a sanction could be classified as a penalty in the cases of depriving liberty or carry punitive and deterrent aims. However, the Court does not apply the purpose issue on disciplinary sanctions. Indeed, even if a disciplinary sanction carries punitive and

Trechsel S. Human Rights in Criminal Proceedings. New York: Oxford University Press, 2005, p, 19.

8 "It is a rule that is directed, not towards a given group possessing a special status - in the manner, for example, of disciplinary law -, but towards all citizens", Öztürk v. Germany $\$ 53$.

9 Weber v. Switzerland $\$ 33$.

10 Barkhuysen T., van Emmerik M., Jansen O. and Fedorova M. in Right to a Fair Trial, Theory and Practice of the European Convention on Human Rights Fourth Edition Pieter van Dijk, Fried van Hoof, Arjen van Rijn and Leo Zwaak (eds.), Cambridge; Antwerp; Portland: Intersentia, 2018, p. 528.

11 The first one is the Engel judgment, in which the definition of nature typed under the fact of deprivation of liberty $(\$ 82)$. The second and more qualified fact, 'the purpose of sanction' was added to this evaluation in the Öztürk judgment ( $\$ 53)$. "According to the ordinary meaning of the terms, there generally come within the ambit of the criminal law offences that make their perpetrator liable to penalties intended, inter alia, to be deterrent and usually consisting of fines and of measures depriving the person of his liberty". 
deterrent aims, it is not treated as a penalty by the Court, because it is directed only towards a particular group. ${ }^{12}$ For example, as the prison disciplinary sanctions are directed towards a group possessing a special status, namely prisoners, they fall outside the scope of the concept of penalty. ${ }^{13}$ In this respect, imposition of solitary confinement as a sanction is not a penalty, as it does not deprive liberty. ${ }^{14}$ This indicates that the second criterion is more decisive than the third.

However, in the case of depriving liberty, it will be concluded that the sanction has a criminal rather than a disciplinary nature. In this case, the third criterion becomes determinant and excludes the second. Thus, in those cases concerning various types of disciplinary sanctions, such as military, ${ }^{15}$ prison, ${ }^{16} \operatorname{court}^{17}$ and the assembly, ${ }^{18}$ the sanctions carrying a potential risk of deprivation of liberty were all classified as penalty. In this connection, the Court also considered the possibility that a criminal issue had been regulated as a disciplinary sanction. In fact, in Ezeh and Connor judgment, the Court observed that although the acts such as threatening or assault were subject to disciplinary sanctions, these were actually criminal offences. ${ }^{19}$ Therefore, if a sanction deprives liberty, it is irrelevant how it is named in domestic law.

The degree of the severity of the sanction will further complicate this picture with its subjectivity. This is because even a sanction that can be classified as penalty according to other criteria is excluded from this classification on the grounds that it carries sufficient severity. Moreover, there is no threshold to evaluate the state of severity. For example, in the Engel case, the ECtHR concluded the two-day arrest was not severe enough to qualify the sanction as a penalty. ${ }^{20}$ Thus, the "severity" element overcomes the "nature" element, and with the second criterion, ensures that disciplinary sanctions are not penalties.

\section{Questioning the definition made by the court}

For the Court, "disciplinary sanctions are generally designed to ensure that the members of particular groups comply with the specific rules governing their

12 "Although the size of the potential fine is such that it must be regarded as having a punitive effect, the severity of this sanction in itself does not bring the charges into the criminal sphere", MüllerHartburg v. Austria $\$ 46$.

13 Ezeh and Connors v. UK $\$ 103$.

14 Štitić v. Croatia $\$ 61$.

15 "In a society subscribing to the rule of law, there belong to the "criminal" sphere deprivations of liberty liable to be imposed as a punishment', Engel $v$ Netherlands $\$ 82$.

16 Campbell and Fell v UK $\$ 72$.

17 Weber v. Switzerland $\$ 34$.

18 Demicoli v. Malta $\$ 34$.

19 Ezeh and Connors v. UK $\$ 129$.

20 Engel v. Netherlands $₫ 85$. A more up-to-date application was in the Brandao Ferreira v. Portugal decision, in which the Court ruled that the detention of the applicant did not amount to a deprivation of liberty given that he was not locked up during the execution, but continued to discharge his military duties virtually as usual. 
conduct". ${ }^{21}$ In this respect, the implementation is developed under the forms of professional groups and special groups, and will be examined under these two headings.

\subsection{Implication on professional identities}

Since the term professional groups includes identities such as doctors, judges and civil servants, there is no serious problem in the field of application. In the case law of the Court, the sanctions imposed on these professionals are generally considered a civil dispute, with some exceptions. For example in the Suküt decision, ${ }^{22}$ even though the dispute concerned the applicant's discharge from the army for breaches of discipline, the Court concluded that the question of the "special bond of trust and loyalty" between the applicant and the State and Article 6 is completely inadmissible.

However, in the others, disciplinary sanctions that halt professional activity are considered civil disputes, treated under the civil head of Article 6. In this respect, a temporary ban on practising as a lawyer and being ordered to be struck off the register, ${ }^{23}$ the compulsory retirement of a civil servant, ${ }^{24}$ the suspension of a judge from duty, ${ }^{25}$ and fines imposed on a solicitor, ${ }^{26}$ do not constitute a penalty.

The sanction imposed in this context is based solely on professional rules, and it may not be considered that the person has undergone another trial for the same act. In this respect, for example, imposition of a disciplinary sanction besides a criminal penalty shall not violate the rule of ne bis in idem. ${ }^{27}$ However, it should be also kept in mind that, in a legal system, multiple sanctions for the same act are accepted only if it includes integrated sanctions for different purposes. ${ }^{28}$ Consequently, the imposition of multiple fines, both as a judicial penalty and as a disciplinary action, may be contrary to the rule of ne bis in idem.

\subsection{Implication on special groups}

The Court's intended meaning of a "special status" is not limited to professional identity. The motivation for the rules for these groups being regarded as disciplinary sanctions is open to discussion, given the contradiction of the results in practice.

One of the most controversial examples in this context is the discipline practices to which the participants in the judicial activity are subject. Although judges and lawyers also participate in this activity, as mentioned above, they already have their

${ }^{21}$ Weber v. Switzerland $\$ 33$.

22 Suküt v. Turkey (admissibility decision).

23 Müller-Hartburg v. Austria $\$ 39$.

${ }^{24}$ Moullet v. France (admissibility decision).

25 Ramos Nunes De Carvalho E Sá v. Portugal \$ 127.

${ }^{26}$ Brown v. UK (admissibility decision).

27 Müller-Hartburg v. Austria $\$ 63$.

28 A and B v. Norway $\$ 123$. 
own disciplinary regimes. However, there is debate over the scope of disciplinary sanctions imposed on those who are parties to a trial. In the judgment of Weber, the Court concluded that the parties to the proceedings could not be categorised as professional groups such as judges and lawyers. ${ }^{29}$

However, in the Ravnsburg judgment, in which the applicant was just a part of the proceeding respondent to several fines imposed due to his improper expressions to a national court, the ECtHR concluded in the opposite direction. Here, the ECtHR argued that the authority to impose sanctions to restore order to the courts was of a disciplinary, rather than a criminal nature. This justification, however, was based not only on the nature of the offence, but also due to its categorization as a disciplinary sanction in the domestic law of the Contracting States. ${ }^{30}$ The Court continued this line in the subsequent judgment of Putz. ${ }^{31}$

Another possibly controversial group may be politicians, who face various types of sanctions. In fact, the problem here is whether it is possible to separate political problems from criminal ones. For example, in the case of Pierre-Bloch, the applicant was banned from participating in the elections by the election commission for one year due to exceeding the legal spending limit, and was ordered to make a payment in excess of the amount. However, the Court classified the subjected dispute as electoral rather than criminal or civil, without involving any disciplinary issues. This conclusion was open to criticism because it is arguable that, as anyone can run for parliament, the issue is not disciplinary and politicians do not constitute a special group. ${ }^{32}$

The Court continued this line, even going so far as to remove a politician from a public duty. For example in the Paksas judgment the Court decided that the dismissal of President of Lithuania by impeachment reflected a constitutional responsibility, rather than criminal or disciplinary one. Here, the Court took into account the fact that the decision to remove the President from office was taken not by the Constitutional Court but by Parliament. ${ }^{33}$ After some years, in the Haarde judgment, the impeachment of the PM was treated as a criminal procedure, because this parliamentary procedure led to a criminal court judgment. ${ }^{34}$

\section{Conclusions}

The ECtHR does not consider a sanction as penalty unless directed at the whole society. In the Court's view, a disciplinary sanction must deprive from liberty to be defined as a penalty. Moreover, even two days' arrest was not considered to carry sufficient severity to be treated as a penalty. Additionally, while a fine is regarded

29 Weber v. Switzerland \$ 33.

30 Ravnsborg v. Sweden $\$ 34$.

31 Putz v. Austria $\$ 33$.

32 Pierre-Bloch v. France $\$ 54$.

33 Paksas v. Lithuania $\$ 66$.

34 Haarde v. Iceland \$ 78. 
as being within the concept of autonomous penalty, disciplinary sanctions that may have more serious consequences are not subject to the same regime. Such an application involving the Engel criteria yields subjective results.

In the Court's definition, disciplinary offences are committed by members of particular groups. In this respect, professional groups provide a more specific view in terms of scope. However, the other so-called "special groups" create a discrepancy in scope. The persons involved in judicial process without any professional function do not constitute a special group opposite to the case law. The extent to which politicians are included in the definition of this particular group is also controversial. These problems indicate a need for revision of the Engel criteria, and the definition of disciplinary sanctions on which the Court's case law is based.

\section{BIBLIOGRAPHY}

\section{Literature}

1. Barkhuysen T., van Emmerik M., Jansen O. and Fedorova M. Right to a Fair Trial. Theory and Practice of the European Convention on Human Rights. van Dijk P., van Hoof F., van Rijn A. and Zwaak L, (eds.), Cambridge; Antwerp; Cambridge; Antwerp; Portland: Intersentia, 2018.

2. Harris D., O’Boyle M., Bates E., Buckley C. Law of the European Convention on Human Rights. New York: Oxford University Press, 2014.

3. Trechsel S. Human Rights in Criminal Proceedings. New York: Oxford University Press, 2005.

\section{Legal practice}

1. ECtHR judgment of 08 June 1976 in case Engel and the others v. the Netherlands (application No. $5100 / 71$ et al.).

2. ECtHR judgment of 10 February 1983 in case Albert and Le Comte v. Belgium (application Nos $7299 / 75 ; 7496 / 76)$.

3. ECtHR judgment of 21 February 1984 in case Öztürk v. Germany (application No. 8544/79).

4. ECtHR judgment of 28 June 1984 in case Campbell and Fell v. the UK (application No. 7819/77 and 7878/77).

5. ECtHR Judgment of 22 May 1990 in case Weber v. Switzerland (application No. 11034/84).

6. ECtHR judgment of 27 August 1991 in case Demicoli v. Malta (application No. 13057/87).

7. ECtHR judgment of 23 March 1993 in case Ravnsborg v. Sweden (application No. 14220/88).

8. ECtHR judgment of 22 February 1996 in case Putz v. Austria (application No. 18892/91).

9. ECtHR judgment of 21 October 1997 in case Pierre-Bloch v. France (application No. 24194/94).

10. ECtHR admissibility decision of 24 November 1998 in case Brown v. UK (application No. 38644/97).

11. ECtHR judgment of 9 October 2003 in case Ezeh and Connors v. UK (application No. 39665/98 and 40086/98).

12. ECtHR admissibility decision of 11 September 2007 in case Suküt v. Turkey (application No. 59773/00).

13. ECtHR judgment of 13 September 2007 in case Moullet v. France (application No. 27521/04). 
14. ECtHR judgment of 8 November 2007 in case Štitić v. Croatia (application No. 29660/03).

15. ECtHR judgment of 6 January 2011 in case Paksas v. Lithuania (application No. 34932/04).

16. ECtHR judgment of 19 February 2013 in case Müller-Hartburg v. Austria (application No. 47195/06).

17. ECtHR judgment of 15 November 2016 in case $A$ and B v. Norway (applications No. 24130/11 and 29758/11).

18. ECtHR judgment of 23 November 2017 in case Haarde v. Iceland (application No. 66847/12).

19. ECtHR judgment of 6 November 2018 in case Ramos Nunes de Carvalho e Sá v. Portugal (application No. 55391/13 et al.). 